\title{
Loxoclase (Felsites loxoclasius), a new member of the felsite genus
}

\section{A. Breithaupt}

To cite this article: A. Breithaupt (1846) Loxoclase (Felsites loxoclasius), a new member of the felsite genus, Philosophical Magazine Series 3, 29:192, 150-151, DOI: 10.1080/14786444608645601

To link to this article: http://dx.doi.org/10.1080/14786444608645601

曲 Published online: 30 Apr 2009.

Submit your article to this journal $\sqsubset$

Џ Article views: 2

Q View related articles ¿ 
If we consider, with $\mathrm{M}$. Frankenheim, $\mathrm{Cu}_{8} \mathrm{~S}$ to be isomorphous with $\mathrm{ZnS}$ and $\mathrm{FeS}$, the following simple formula results :-

$$
\left.\begin{array}{r}
\left(\mathrm{Cu}_{2} \mathrm{~S}\right)^{4} \\
(\mathrm{Zn} \mathrm{S})^{4} \\
(\mathrm{Fe} \mathrm{S})^{4}
\end{array}\right\} \mathrm{As}_{2} \mathrm{~S}_{3} \text {. }
$$

Copper blende essentially differs from tennantite in having a portion of $\mathrm{Cu}_{2} \mathrm{~S}$ replaced by $\mathrm{Zn} \mathrm{S.-Poggendorff's} \mathrm{Annalen.}$

\section{LOXOCLASE (FELSITES LOXOCLASIUS), A NEW MEMBER OF THE FELSITE GENUS. BY A. BREITHAUPT.}

Amongst a number of North American minerals, for which $I$ have to thank Mr. Shepard, were several of the genus Felsite, and one in particular which at first sight I took for pegmatolith, but which turns out to be a new and remarkable species. This mineral in many respects resembles oligoclase: I have therefore, in the following description, pointed out those peculiarities which render it distinct. Lustre, between vitreous and greasy; pearly on the most perfect cleavage-surface.

Orthoclastic.-Primary form, oblique rhombic prism, $+P \infty(P)$ $=63^{\circ} 38^{\prime}$ towards the chief axis; $-\mathrm{P} \infty(x)=65^{\circ} 37^{\prime}$ towards the chief axis; $\mathrm{P}: y=3 x=99^{\circ} 45^{\prime} ; \mathrm{P}: \mathrm{T}=112^{\circ} 30^{\prime} ; \mathrm{P}: l=112^{\circ} 50^{\prime}$; $\mathrm{P}: \mathrm{M}=90^{\circ} 0^{\prime}$ (oligoclase $\mathrm{P}: \mathrm{M}=86^{\circ} 45^{\prime}$ ); $\mathrm{M}: \mathrm{T}^{\prime}=120^{\circ} 15^{\prime}$; $M: l=119^{\circ}, 25^{\prime} ; \mathrm{T}: l=120^{\circ} 20^{\prime}$. Cleavage, perfect hemidomatic ; very distinct in the direction of the short diagonal ; indistinct approaching distinctness in the direction of the long diagonal; hemiprismatic, in fragments Fracture, uneven to conchoidal and hackly. Hardness $=7 \frac{1}{2}$ to $7 \frac{3}{4}$ (of Breithaupt's scale) (oligoclase $7 \frac{3}{4}$ to $8 \frac{1}{2}$ ). Specific gravity $=2 \cdot 609$ to $2 \cdot 620$ (oligoclase $2 \cdot 644$ to $2 \cdot 662$ ). Colour, yellowish-gray, yellowish-white, pea yellow, bluish-gray. Translucent in thin laminæ to transparent. 'The oblique cleavage in the direction of the long diagonal is characteristic of loxoclase, although not always very distinct, hence its name. Its specific gravity is also higher than any other of the orthoclastic felsites. It appears subject to decay by exposure to the atmosphere.

Two analyses performed by Prof. Plattner; the one by means of hydrofluoric acid $(a)$, the other by carbonate of soda $(b)$; the mean of the two (c) showed it to possess the following composition:-

\begin{tabular}{|c|c|c|c|}
\hline Silica & a. & $\begin{array}{c}b . \\
63 \cdot 50\end{array}$ & $\begin{array}{c}c . \\
63 * 50\end{array}$ \\
\hline Alumina $\ldots \ldots \ldots \ldots \ldots$ & $20 \cdot 48$ & $20 \cdot 10$ & $20 \cdot 29$ \\
\hline Oxide of iron . . . . . . . . . . & $0 \cdot 65$ & 0.70 & $0 \cdot 67$ \\
\hline Potash.............. & 3.03 & & $3 \cdot 03$ \\
\hline Soda .... & $8 \cdot 76$ & & $8 \cdot 76$ \\
\hline$\underset{\text { Magnesia }}{\text { Lime } \ldots \ldots \ldots \ldots \ldots \ldots \ldots \ldots \ldots \ldots}$ & $\begin{array}{l}3 \cdot 40 \\
\text { trace }\end{array}$ & $\begin{array}{l}3.04 \\
\text { trace }\end{array}$ & $3 \cdot 22$ \\
\hline Water and fluoride of silicon. . & & $1 \cdot 23$ & $1 \cdot 23$ \\
\hline
\end{tabular}

for which the general formula is $\mathrm{RO}, \mathrm{SO}_{3}+\mathrm{R}_{2} \mathrm{O}_{3},\left(\mathrm{SO}_{3}\right)^{2}$, as also for oligoclase. Loxoclase affords therefore a remarkable example of 
dimorphism, for oligoclase is plagioelastic, and yet both must be classed under the same genus. Loxoclase fuses before the blowpipe with difficulty (fusibility between adular and labrador), and shows in the outer flame an intense soda reaction. (Oligoclase melts pretty easily.) Heated in a small glass bulb it gives out a little water and fluoride of silicon, and is very imperfectly decomposed by hot muriatic acid. Loxoclase occurs with pyroxen, graphite, and calcareous spar, upon the two former covered by the latter, at Hammond, in the State of New York.-Poggendorff's Annalen.

\section{METEOROLOGICAL OBSERVATIONS FOR JUNE 1846.}

Chiswick.-June 1, 2. Slight haze : cloudless. 3. Slight haze : very dry air : clear and fine. 4-6. Hot and dry. 7. Sultry. 8, 9. Cloudy and fine. 10. Overcast. 11, 12. Very fine. 13, 14. Hot and dry. 15. Cloudless. 16-18. Hot and dry, with slight haze. 19. Foggy : excessively hot : clear at night. 20. Hot and sultry. 21. Uniformly overcast : fine. 22. Sultry : excessively hot : rain : at night thunder, lightning, and heavy rain. 23, 24. Densely clouded. 25. Fine. 26. Overcast : heavy showers. 27, 28. Cloudy and fine. 29. Fine, with clouds : windy : clear at night. 30 . Cloudy and fine : overcast.

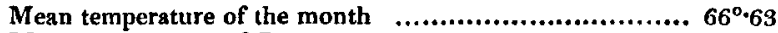

Mean temperature of June 1845 ....................................62 $62 \cdot 14$

A verage mean temperature of June for the last twenty years $60 \cdot 88$

Average amount of rain in June ............................. 1.88 inch.

Boston.-June 1. Cloudy. 2. Fine : half-past $110^{\prime}$ clock A.M. thermometer $75^{\circ}$ : $20^{\prime}$ clock P.M. $78^{\circ}$. 3. Fine: $30^{\circ}$ clock P. M. thermometer $80^{\circ}$. 4. Fine. 5. Cloudy. 6. Fine : quarter-past 2 o'clock P. M. thermometer $82^{\circ}$. 7. Fine. 8 . Cloudy : lightning A.M. 9, 10. Cloudy. 11-17. Fine. 18. Fine : quarter-past 11 o'elock A.M. thermometer $80^{\circ}$. 19. Fine. 20. Cloudy, 21. Fine. 22. Cloudy : rain P. M., with thunder and lightning. 23. Rain : rain early A.M.: rain P. M. 24. Fine. 25. Fine: rain and hail, with thunder and lightning P.M. 26-28. Cloudy. 29, 30. Fine.- The past month has been considerably warmer than any month of my observations.

Sandwick Manse, Orkney.-June 1-8. Fine. 4. Fine : bright : fine, 5. Fine : bright : cloudy. 6. Damp. 7. Damp: cloudy. 8. Cloudy. 9. Damp: fog : cloudy. 10. Cloudy : rain. 11. Bright: rain. 12, 18. Bright : clear. 14, 15. Bright: cloudy. 16. Bright : clear. 17, 18. Fine. 19. Thunder and hail*: cloudy. 20. Clear : fine. 21. Clear. 22. Cloudy : fog. 23. Rain and thunder : thunder and rain. 24. Drizzle : thunder and drops. 25, 26. Clear. 27. Rain: clear. 28. Bright : cloudy. 29. Bright : drops. 30. Bright : showers.

Applegarth Manst, Dumfries-shire.-June 1-6. Very fine. 7. Very fine: thunder. 8. Fine soft rain. 9, 10. Slight shower. 11. Fair, but cloudy. 12-16. Fair and fine. 17. Fair and fine : warn. 18. Fair and fine: thunder. 19. Slight drizzle : thunder. 20. Dry and withering. 21. Very warm and withering, 22. Very warm: showers : thunder and hail. 23. Very heavy rain. 24,25 . Showers : fair P.M. $26-29$. Heavy rains. -30 . Very heavy rain.

Mean temperature of the month $\ldots . . . \ldots \ldots \ldots \ldots \ldots . \ldots 3^{\circ} \cdot 2$

Mean temperature of June 1845 .................... $56 \quad \cdot 5$

Mean temperature of June for twenty-three years. $55 \quad-7$

Mean rain in Jume for eighteen years ............... 3 inches.

* The most severe thunder-storm ever remembered : one man was killed, others knocked down, and the lightning struck various places. It was at its height between six or seven o'clock A,M. 